\title{
SHIPMENT INDUSTRY DEVELOPMENT STRATEGY WITH INTERPRETATIVE STRUCTURAL MODELING (ISM) APPROACHES
}

\author{
Sutikno Wahyu Hidayat, Fa'iq Mumtaz M, Cahyanto \\ Indonesian Naval Technology College, \\ Bumimoro-Morokrembangan, Surabaya 60187, Indonesia
}

\begin{abstract}
The shipping industry sub-sector, although contributing quite significantly to Indonesia's economic growth, has not yet included leading commodities in industrial development in Indonesia. The problem that must be examined in the effort to develop the shipping industry is the absence of the determination / application of the right strategy to be able to maximize the potential of the existing potential that enables the shipping industry to become a competitive industry. The research is carried out with the following stages: - Searching for sources of information that can provide an overview of the boundaries, subject matter of the study, developments and problems in the shipping sub sector, territorial understanding, understanding of management strategies, to then set the goal formulation as the direction of conducting research. - Conducting an expert survey to review and determine the elements / sub elements related to the development strategy of the shipping industry real sector of the shipping industry. - Designing a structuring system by conducting studies / determination of the key elements of development, with Interpretative Structural Modeling (ISM). Based on the results of expert studies, 4 elements and 12 sub elements were determined that have strong interactions with the development of the shipping industry in Indonesia. The elements are then analyzed by the level of interaction with the ISM-VAXO technique. The first step is to study the contextual relationship in the form of the SSIM-VAXO Matrix. This method has been able to classify all sub-elements into four quadrants based on the value of Drive Power and Dependence and in the hierarchical structure based on Ranking and Level, which then informs the key subelements of the development of the shipping industry, namely: sub-elements: Provision of human resources with shipping knowledge and skills adequate (7) and sub-elements Improvement of managerial skills training program (8).
\end{abstract}

Keywords: Shipping industry, development strategy, ISM

\section{INTRODUCTION}

The shipping industry sub-sector, although it has made a significant contribution to the economic growth of the Indonesian region, has not yet included leading commodities in the development of the shipping industry. The shipping industry is the foundation of hope in perfecting success in the industrial sector as an industry that processes and adds value to industrial products in a sustainable manner. The business touch makes the shipping industry one of the main pillars of the economy in determining its development strategy, in addition to the technical aspects, it must also formulate a development strategy that is able to optimize the potential of resources owned by an area.

Strategy formulation requires in-depth study because it is the first step that really determines the achievement of the goals set. This study aims to design the stages of strategy formulation by conducting a study of the interaction between elements / sub elements of the development of the shipping industry as a result of expert surveys, to get the formulation of key elements / sub elements. The problem that must be examined in the effort to develop the shipping industry is the absence of the determination / application of the right strategy to be able to maximize the potential of the existing potential that enables the shipping industry to become a competitive industry and realize industrial revitalization.

At the National Ship Industry Symposium II (1987) formulating the shipping industry as an interdisciplinary activity that utilizes natural resources (industry) as industrial raw materials. The contribution of the shipping industry (including the shipping industry-based industry) is vital for the economic growth of developing countries. According to Brown (1994) more than half of all manufacturing activity in developing countries is the shipping industry. By the end of the 20th century about 37 percent of manufacturing in the Asia and Pacific region was in the shipping industry sector. The shipping industry should be used as a foundation for the implementation of resource based strategy is the latest approach in the phenomenon of globalization and competitive strategies that can be used in rearranging Indonesia's international marketing strategy.

The problem examined and tried to be raised in the development of the shipping industry is the absence of the determination / application of the right strategy to be able to maximize the potential of the existing potential that allows the shipping industry to become a competitive industry. With this research, it is expected that key sub-elements will 
be developed in the development of a shipping industry.

In the writing of this journal is also used a lot of literature as a reference to support the research conducted, such as including the following: Manajemen strategik dan manajemen operasional Serta implementasinya pada lembaga pendidikan (Mappasiara, 2018), Analisis faktor penting dalam pengelolaan perikanan budidaya di keramba jaring apung berkelanjutan dengan metode interpretative structural modeling (ism) di waduk cirata, jawa barat (Ani Widiyati, 2009), Mengembangkan Koperasi Syariah di Indonesia: Pendekatan Interpretative Structural Modelling (ISM) (Rusydiana, 2018), Beyond Generic Models for Information System Quality: The Use of Interpretive Structural Modeling (ISM) (Kanungo, 2002), Strategi Meningkatkan Preferensi Perbankan Syariah Indonesia dalam Menggunakan Pembiayaan Bagi Hasil (Ascarya, 2012), Using Interpretive Structural Modelling in Strategic Decision-making Groups (Bolaños, 2005), Gorvett, Rick, and Ningwei. Liu. 2007. "Using Interpretive Structural Modeling to Identify and Quantify Interactive Risks." Call Paper Program 2007 ASTIN Colloquium. USA. (Gorvett, 2007)

This research is organized as follows, chapter 1 introduction, chapter 2 shows material and methodology, chapter 3 shows the results of data and discussion, chapter 4 conclusion.

\section{MATERIALS AND METHODS}

\subsection{Definition of Strategy management}

Strategy Management is defined as the art and knowledge to formulate, implement, and evaluate cross-functional decisions that enable an organization to achieve its objectives. The principle benefit of strategic management is that it helps organizations make better strategies using a more systematic, logical and rational approach to strategic choices. Strategic management teaches how to maximize the effectiveness of the organization as a whole, in addition to teaching how to improve its efficiency (Burhanuddin, 1994).

The three elements that are the focus of management are the organization, the environment and strategy. Organizational elements related to the interests of actors (individuals) both individually and organization in achieving / implementing the vision, mission and goals of the organization including industry. Environmental elements are related to economic aspects (market forces and competition), sociocultural, geographical location, government, and technology. The element of strategy is related to the future goals (future intention) and the competitive advantage of the organization (Siagian, 2001)

\subsection{Interpretative Structural Modeling (ISM).}

Interpretative Structural Modeling (ISM) is a technique used in modeling that is able to synchronize the opinions of experts in providing a concrete picture of the hierarchical structure of sub- elements of each system element, and in finding key sub-elements and the character of each subelement, as a useful knowledge base for developing integrated and cross-sector industrial development planning strategies for the shipping industry (Machfud, 2001).

According to (Saxena, 1992), ISM is a structuring tool in descriptive modeling techniques that are used primarily for assessment by a team but can also be used by a researcher. Structural models are produced in order to capture complex matters of a system through patterns designed using graphics and sentences. The contextual relationships among ISM engineering sub-elements can be grouped into several types and interpretations.

\subsection{Research Stages.}

The study was conducted in the following stages:

a. Conducting information sources that can provide an overview of the boundaries, main points of study, developments and problems in the animal husbandry sub-sector, territorial understanding, strategic management understanding, and then set the goal formulation as the direction of conducting research.

b. Conducting an expert survey to study and determine the elements / sub elements related to the development strategy of the shipping industry sector of the real industry of the shipping industry, determine the type of industry of the chosen shipping industry used as the object of the development system study.

c. Designing a structuring system by conducting a study / determination of key elements of development, with Interpretative Structural Modeling (ISM)

The steps in the ISM-VAXO technique are:

1). Structural Self Interaction Matrix Formulation VAXO (SSIM-VAXO)

2). Transform SSIM - VAXO into Reachability Matrix (RM) binary numbers

3). Transitive matrix testing Classification of subelements based on Driver Power (DP) and Dependence (D) Arrangement of hierarchy based on the ranking of sub-elements

Table 1. Symbols of relationships and contextual definitions between ISM-VAXO elements

\begin{tabular}{|c|l|}
\hline Symbol & Relationship between row (i) and column (ii) elements \\
\hline $\mathrm{V}$ & $\begin{array}{l}\text { There is a contextual relationship between the element Ei and the } \\
\text { element Ej, but not vice versa }\end{array}$ \\
\hline $\mathrm{A}$ & $\begin{array}{l}\text { There is a contextual relationship between the Ej element and the } \\
\text { Ei element, but not vice versa }\end{array}$ \\
\hline $\mathrm{X}$ & $\begin{array}{l}\text { There is a reciprocal contextual relationship between the element } \\
\text { Ei and the element Ej }\end{array}$ \\
\hline 0 & $\begin{array}{l}\text { There is no reciprocal contextual relationship between the element } \\
\text { Ei and the element Ej }\end{array}$ \\
\hline
\end{tabular}




\subsection{Research Methodology.}

To solve problems in the observed research, steps are needed and determined to describe the approach and model of the problem. The steps taken are:

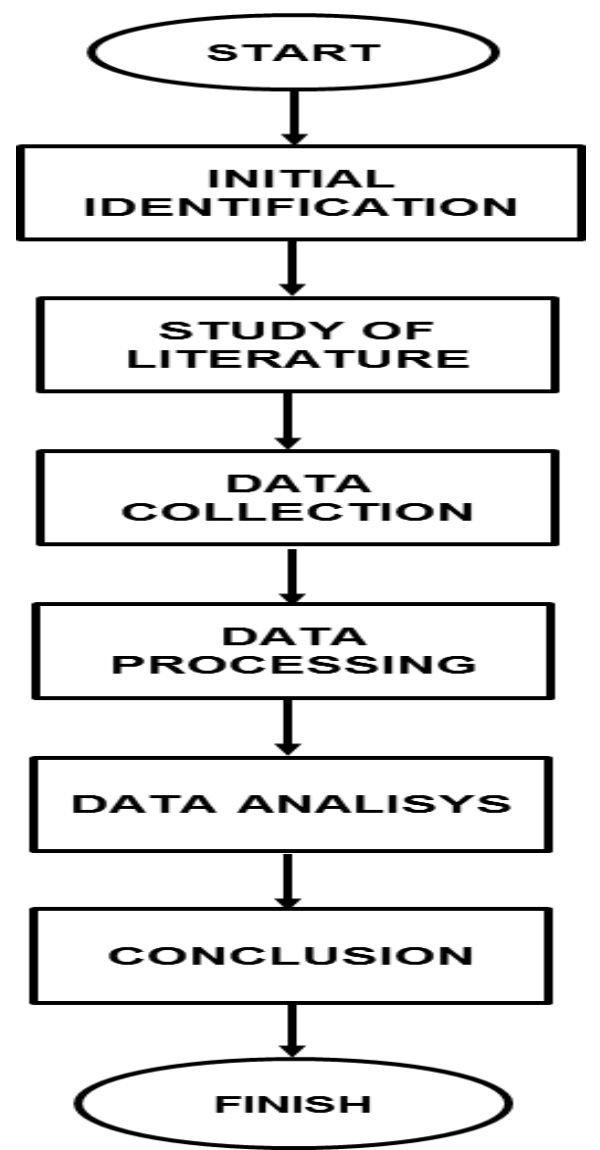

Fig. 1. Research Methodology Flowchart.

Target: the aim of this research is to produce a decision support system to look for key elements in the development of the shipping industry.

Steps: the steps of this research are step 1 Determine the criteria step 2 determine the suitability of each alternative ranking in each criterion step 3 enter interview data in the table, quantitative test analysis What is step 2, step 3 Make a decision based on matrix criteria, then the matrix equation is based the normalization of behavior that is adjusted to the type of attribute (attribute attribute or cost benefit) so that a normalized matrix is obtained, step 4 the final result is obtained from the interpretative structural modeling (ISM) approach in the form of key variables that are very influential in the development of the shipping industry, step 4 provides suggestions for improvement and conclusions.

\section{RESULT AND DISCUSSION}

After brainstorming and in-depth interviews, various elements and sub-elements of the development of the shipping industry are determined as shown in Table 2.
Table 2. Elements and Sub Elements of development

\begin{tabular}{|l|l|}
\hline \multicolumn{1}{|c|}{ Elemen } & \multicolumn{1}{|c|}{ Sub Elemen } \\
\hline 1. Production & $\begin{array}{l}\text { 1. a new shipbuilding order or at least ship } \\
\text { maintenance. } \\
\text { 2. economic growth and competitive logistics } \\
\text { costs. } \\
\text { 3. follow the development of information } \\
\text { technology or digitalization systems in sea } \\
\text { transportation. }\end{array}$ \\
$\begin{array}{l}\text { 4. Diversify business from just building and } \\
\text { maintaining ships } \\
\text { 5. Do the best work possible by prioritizing } \\
\text { shipping safety and security aspects. }\end{array}$ \\
\hline $\begin{array}{l}\text { 2. Materials / raw } \\
\text { materials }\end{array}$ & $\begin{array}{l}\text { 1. Increased availability of high quality } \\
\text { materials or materials (steel and machinery) } \\
\text { 2. Provision of material by the material } \\
\text { processing industry or materials } \\
\text { 3. Government Regulation }\end{array}$ \\
\hline 3. Management & $\begin{array}{l}\text { 1. Provision of human resources with } \\
\text { adequate shipping knowledge and skills } \\
\text { 2. Enhancing managerial skills training } \\
\text { programs } \\
\text { 3. Modernization of procurement, production } \\
\text { and distribution systems }\end{array}$ \\
\hline Results & $\begin{array}{l}\text { 1. Development of the shipping industry } \\
\text { business to increase the added value of the } \\
\text { shipping industry's products } \\
\text { 2. Product research and development } \\
\text { 3. Mastery of the whole marketing aspects }\end{array}$ \\
\hline Technology
\end{tabular}

Based on the results of expert studies, 4 elements and 12 sub elements were determined that have strong interactions with the development of the shipping industry in Indonesia. The 12 sub elements (henceforth called elements) are then analyzed by the level of interaction with the ISM technique. The first step is to study the contextual relationship in the form of the SSIM-VAXO Matrix as shown in Figure 2:

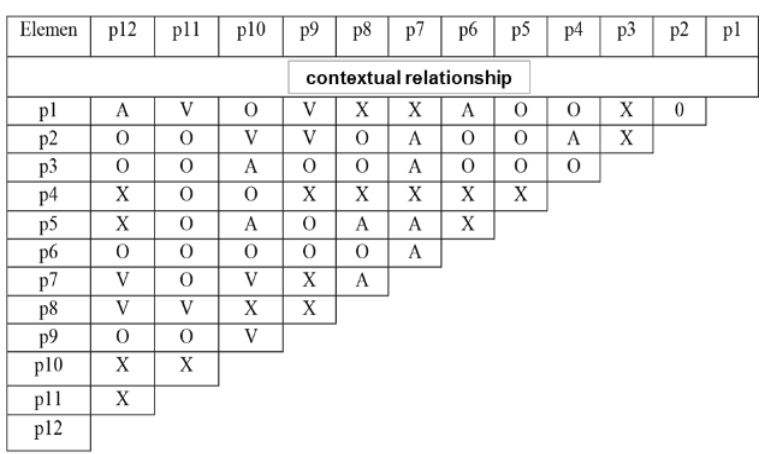

Figure 2. SSIM - VAXO Matrix for the development of the shipping industry

Elements of the shipping industry development:

1. a new shipbuilding order or at least ship maintenance.

2. economic growth and competitive logistics costs.

3. follow the development of information technology or digitalization systems in sea transportation.

4. Diversify business from just building and maintaining ships

5. Increased availability of high quality machinery) 
6. Provision of material by the material processing industry or materials

7. Provision of human resources with adequate shipping knowledge and skills

8. Enhancing managerial skills training programs.

9. Modernization of procurement, production and distribution systems.

10. Development of the shipping industry business to increase the added value of the shipping industry's products

11. Product research and development

12. Mastery of the whole marketing aspects

Table 3. Final results of the Matrix Reachability of the shipping industry development element

\begin{tabular}{|c|c|c|c|c|c|c|c|c|c|c|c|c|c|c|}
\hline \multirow{3}{*}{$\begin{array}{l}\text { SYMBOL } \\
\text { PROGRAM }\end{array}$} & \multirow{2}{*}{\multicolumn{12}{|c|}{ 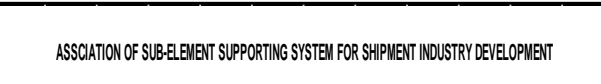 }} & \multirow{3}{*}{ DP } & \multirow{3}{*}{ R } \\
\hline & & & & & & & & & & & & & & \\
\hline & $p 1$ & $\mathrm{p2}$ & $p_{3}$ & $\mathrm{p4}$ & $p 5$ & $\mathrm{p} 6$ & $\mathrm{pl}$ & $p 8$ & p9 & p10 & p11 & p12 & & \\
\hline $\mathrm{pl}$ & 1 & 0 & 1 & 0 & 0 & 1 & 1 & 0 & 1 & 0 & 1 & 0 & 6 & 3 \\
\hline$p 2$ & 0 & 1 & 1 & 0 & 0 & 0 & 0 & 0 & 1 & 1 & 0 & 0 & 4 & 4 \\
\hline$p 3$ & 1 & 1 & 1 & 0 & 0 & 0 & 0 & 0 & 0 & 0 & 0 & 0 & 3 & 5 \\
\hline $\mathrm{p4}$ & 0 & 1 & 0 & 1 & 1 & 1 & 1 & 1 & 1 & 0 & 0 & 0 & 7 & 2 \\
\hline p5 & 0 & 0 & 0 & 1 & 1 & 1 & 0 & 0 & 0 & 0 & 0 & 1 & 4 & 4 \\
\hline$p 6$ & 0 & 0 & 0 & 1 & 1 & 1 & 0 & 0 & 0 & 0 & 0 & 0 & 3 & 5 \\
\hline $\mathrm{pl}$ & 1 & 1 & 1 & 1 & 1 & 1 & 1 & 0 & 1 & 1 & 0 & 1 & 10 & 1 \\
\hline$p 8$ & 1 & 1 & 0 & 1 & 1 & 1 & 1 & 1 & 1 & 1 & 1 & 0 & 10 & 1 \\
\hline $\mathrm{pg}$ & 0 & 0 & 1 & 0 & 0 & 0 & $\underline{0}$ & 1 & 1 & 1 & 0 & 0 & 4 & 4 \\
\hline pio & 0 & 0 & 1 & 0 & 1 & 0 & 0 & 1 & 0 & 1 & 1 & 1 & 6 & 3 \\
\hline $\mathrm{p} 11$ & 0 & 0 & 0 & 0 & 0 & 0 & 0 & 0 & 0 & 1 & 1 & 1 & 4 & 4 \\
\hline $\mathrm{p} 12$ & 1 & 0 & 0 & 0 & 1 & 0 & 0 & 0 & 1 & 1 & 1 & 1 & 6 & 3 \\
\hline$D$ & 5 & 5 & 6 & 5 & 7 & 5 & 4 & 4 & 6 & 7 & 5 & 5 & & \\
\hline $\bar{L}$ & 3 & 3 & 2 & 3 & 1 & 3 & 4 & 4 & 2 & 1 & 3 & 3 & & \\
\hline
\end{tabular}
VAXO into Reachability Matrix (RM) binary numbers, then proceed to the third stage, which is a transitive test of consistency in RM to get the final RM matrix as shown in Table 3 . In Table 3 , it appears that Sub element 7 is Provision of human resources who have adequate knowledge and skills, and Sub element 8, namely Improvement of managerial skills programs, rank first with the highest Driver Power (DP) value supported by the Smallest Dependence (D) value.

The fourth stage is mapping the results of the $\mathrm{RM}$ in Table 3 , to the sub-element classification based on Driver Power (DP) and Dependence (D) as in Figure 3:

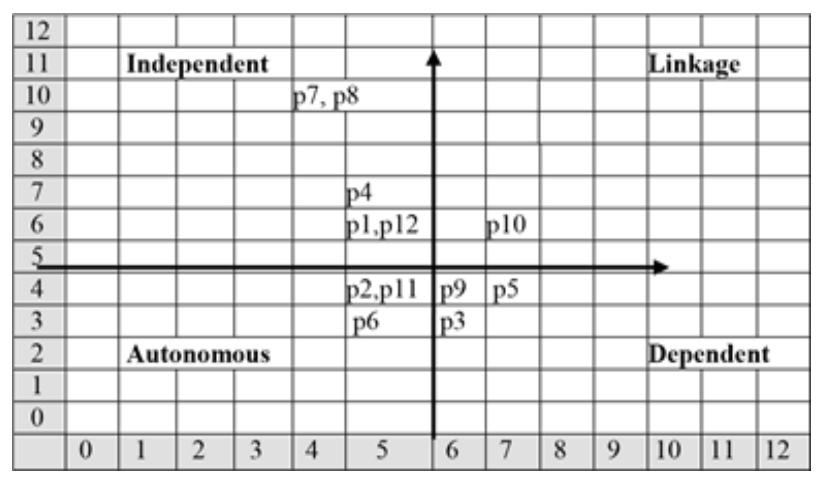

Figure 3. Diagram of classification of shipping industry sub-elements
The sub-element classification is classified into four sectors namely:

Sector 1: Weak driver-weak dependent variables (Autonomous). The relationship between variables in this sector and the system is relatively small or unrelated.

Sector 2: Weak driver-strongly dependent variables (Dependent). The variable in this sector is very dependent on the input and actions given to the system, especially from the linkage variable.

Sector 3: Strong driver-strongly dependent variables (Linkage). Relations between variables in this sector are not stable. Every action on the variable will affect the other variables.

Sector 4: Strong driver-weak dependent variables (Independent). The variables in this sector are called free variables whose elements / sub elements can be considered as key factors of the system.

In the final stage is the preparation of a subelement hierarchy based on the DP rank value and level $D$. The results of the study put the entire subelement of the development of the shipping industry at 4 levels as shown in Figure 4.

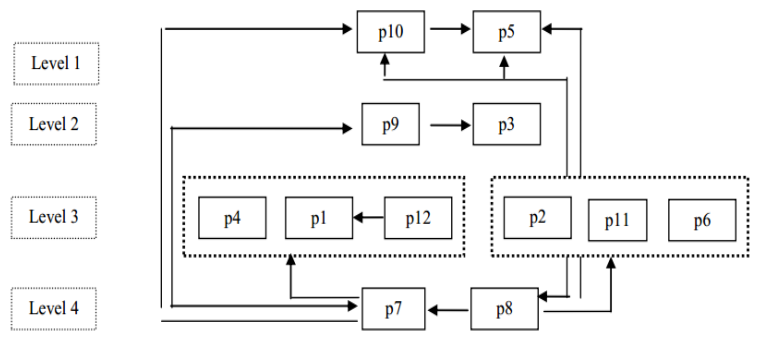

Figure 4. Hierarchical structure of the development sub-elements

Determination of the level of the hierarchy indicates the dependence of certain sub elements on sub elements at the level below it.

\section{CONCLUSION}

The results of expert studies have identified a number of 12 sub elements that qualitatively determine the development of the shipping industry in Indonesia. Interaction behavior between sub elements has been analyzed using the Interpretative Structural Modeling (ISM) method with the ISMVAXO technique. This method has been able to classify all sub-elements into four quadrants based on the value of Drive Power and Dependency and in a hierarchical structure based on Ranking and Level, which then informs the key sub-elements of the development of the shipping industry, namely: the sub-element: Provision of human resources with shipping knowledge and skills adequate (7) and sub-elements Improvement of managerial skills training program (8). 


\section{REFERENCES}

Ani Widiyati, D. D. (2009). Analysis of important factors in the management of aquaculture in sustainable floating net cages with the method of interpretative structural modeling (ISM) in cirata reservoir, West Java. J. Ris. Akuakultur Vol. 4 No. 2, , 277-290.

Ascarya, W. G. (2012). Strategies to Increase Indonesian Sharia Banking Preferences in Using Profit Sharing Funding. Jakarta: Central Banking Education and Studies Department, Bank Indonesia.

Bolaños, R. E. (2005). Using Interpretive Structural Modelling in Strategic Decision-making Groups." Management Decision 43 (6). Emerald Group Publishing Limited, 877-95.

Burhanuddin. (1994). Analysis of Management Administration and Educational Leadership.

Jakarta: Bumi Aksara.

Gorvett, R. a. (2007). Using Interpretive Structural Modeling to Identify and Quantify Interactive Risks. USA: Call Paper Program 2007 ASTIN Colloquium.
Kanungo, S. a. (2002). Beyond Generic Models for Information System Quality: The Use of Interpretive Structural Modeling (ISM). Systems Research and Behavioral Science19 (6)., 531-49.

Machfud. (2001). Group decision support model engineering with fuzzy-logic for the development of essential oil agroindustry. Bogor: Institut Pertanian Bogor.

Mappasiara. (2018). Strategic management and operational management and its implementation in educational institutions. jurnal idaarah, vol. 2, no. 1.

Rusydiana, A. S. (2018). Developing Sharia Cooperatives in Indonesia: Interpretative Structural Modeling (ISM) Approach . Jurnal Ekonomi Islam, Volume 9.

Saxena, J. e. (1992). Hierarchy and Classification of Program Plan Element Using Interpretative Structural Modelling. Systems Practice, Vol 12 (6), , 651:670.

Siagian, S. P. (2001). Strategic Management. Jakarta: Bumi Aksara,. 